DOI: $10.17951 / 1 r p .2020 .39 .2 .103-112$

\author{
Magdalena Barabas \\ Uniwersytet Marii Curie-Skłodowskiej \\ Wydział Pedagogiki i Psychologii \\ Instytut Pedagogiki \\ ORCID - 0000-0002-2013-7245
}

\title{
ZACHOWANIA AGRESYWNE UCZNIÓW WOBEC NAUCZYCIELI KATECHEZY
}

\begin{abstract}
Streszczenie: Współczesna szkoła zmaga się w wieloma problemami wychowawczymi. Coraz częstsze przypadki zachowań agresywnych w środowisku szkolnym oraz prężna dynamika ewolucji agresji pod kątem jej kierunku oraz przejawów sprawia, że nie można przejść obojętnie wobec tego problemu. Coraz częściej obiektem zachowań agresywnych staje się nauczyciel, m.in. katecheta. Określenie skali takich zachowań uczniów wobec nauczycieli jest dość trudne z uwagi na to, że wielu pedagogów nie ujawnia takich sytuacji. Celem artykułu jest zwrócenie uwagi na sytuację nauczycieli katechezy w aspekcie zachowań agresywnych uczniów. Artykuł stanowi prezentację badań własnych, które obrazują fragment rzeczywistości szkolnej w kontekście przejawów zachowań agresywnych uczniów wobec katechetów.
\end{abstract}

Słowa kluczowe: agresja, nauczyciel, katecheta

\section{WPROWADZENIE}

Problematyka agresji od wielu lat znajduje się w centrum zainteresowania nie tylko badaczy naukowych z obszaru pedagogiki i psychologii, ale również socjologów, filozofów czy osób zajmujących się kultura popularną. Bez wątpienia stanowi jeden $\mathrm{z}$ wiodących problemów, którym zajmują się badacze wielu dziedzin nauki i który jest analizowany na wielu poziomach: jednostki, rodziny, społeczeństwa czy globu. Najczęściej zjawisko to jest rozpatrywane w kontekście zagrożeń i zachowań ryzykownych dzieci i młodzieży. Stosunkowo niewiele publikacji jest poświęconych zachowaniom agresywnym wobec nauczycieli. Zazwyczaj dotyczą one zjawiska mobbingu rozumianego jako działania mające charakter przemocy 
psychicznej, a polegających na długotrwałym i usystematyzowanym nękaniu, dręczeniu, terroryzowaniu osoby lub osób w miejscu pracy przez inną osobę będącą wobec nich w relacji nadrzędności lub przez grupę ludzi, np. współpracowników (Leyman 1996). Jak zauważają Mościcka i Drabek, „narażenie na mobbing w pracy nauczyciela, a szczególnie negatywny wpływ konsekwencji tego zjawiska (zaburzenia nastroju, wypalenie zawodowe) na funkcjonowanie w środowisku szkolnym może się wiązać z częstszym przejawianiem przez niego zachowań agresywnych wobec uczniów" (Mościcka, Drabek 2010, s. 75). Warto jednak mieć na uwadze, że nauczyciele doświadczają zachowań wrogich i agresywnych również ze strony uczniów (CBOS, Warszawa 2006, Ostrowska 2008, Baczko-Dombi i in. 2011, Strutyńska 2014). Pedagodzy rzadko jednak decydują się głośno o tym mówić, prawdopodobnie nie chcąc posądzenia o brak kompetencji w zakresie dyscyplinowania klasy czy w zakresie umiejętności radzenia sobie z uczniami prezentującymi agresywne zachowania.

W rozważaniach nad pojęciem agresji należy podkreślić, że istnieje wiele różnych definicji tego zjawiska. Termin ten jest dość mocno osadzony zarówno w języku potocznym, jak i w fachowych słownikach różnych dyscyplin naukowych. Według Barona i Richardsona termin „agresja” jest właściwy do opisania „każdej formy zachowania, której celem jest wyrządzenie szkody lub spowodowanie obrażeń innej żywej istocie, motywowanej do uniknięcia takiego potraktowania" (Baron, Richardson 1994, s. 7). Za agresywne uważa się zachowania skierowane wobec kogoś lub czegoś, które wyrządzają krzywdę i prowadzą do wyrządzenia zła, bólu. Istotą takich zachowań jest szkodliwość oraz anormatywność. Agresja może występować w postaci działań antyspołecznych (motywowanych jedynie chęcią szkodzenia) lub w postaci działań prospołecznych, tj. „przynoszących komuś szkodę, lecz realizowanych w imię celów społecznych, np. praworządności, przeciwdziałania krzywdzeniu innych itp." (Miłkowska 2003, s. 39). Surzykiewicz za agresywne uważa „działanie skierowane przeciwko osobom lub przedmiotom, wywołującym u jednostki niezadowolenie lub gniew. Celem jest wyrządzenie szkody przedmiotowi agresji, określonym osobom lub grupom społecznym" (Surzykiewicz 2000, s. 13). Agresja jest także opisywana jako „zachowanie, które jest umyślnym działaniem na szkodę jednostek lub własności i którego nie da się społecznie usprawiedliwić" (Vasta, Haith, Miller 2004, s. 667). Również zachowanie skierowane przeciwko osobom, przedmiotom w postaci napaści słownej lub fizycznej, której efektem są szkody moralne lub materialne, uważane jest za agresję. Jest utożsamiana także z takimi działaniami, myślami i agresywnymi życzeniami oraz z brakiem działań, nieudzieleniem pomocy, których efektem są szkody. Mamy z nią do czynienia, wówczas gdy osoba ocenia sytuację jako zagrażającą poczuciu własnej wartości (por. Poraj 2009). 
Istnieje wiele różnych klasyfikacji dotyczących zjawiska agresji. Z perspektywy formy zachowania można wyróżnić agresję fizyczną i werbalną (Buss 1961, Gruszkowska 2004). Ze względu na związek obiektu ataku z jej główną przyczyną (źródłem gniewu i wrogości) rozróżnia się agresję bezpośrednią (behawioralna) i pośrednią (symboliczna) oraz autoagresję (Buss 1961, Gruszkowska 2004). Z uwagi na siłę zaangażowania można mówić o agresji czynnej (aktywnej) i pasywnej (Buss 1961, Poraj 2009). Interesującego podziału agresji dokonali Philip G. Zimbardo i Floyd L. Ruch, którzy wyróżnili agresję antyspołeczną i prospołeczną. Zdaniem tych badaczy agresja antyspołeczna jest wyrażana w sposób społecznie nieakceptowany, np. poprzez niszczenie różnych przedmiotów, pobicia czy zabójstwa. Agresja prospołeczna zaś służy akceptowanym społecznie celom, takim jak karanie za łamanie zasad czy reguł. Pewnym wymiarem agresji prospołecznej jest współzawodnictwo, które jest częstym elementem współczesnego świata (Zimbardo, Ruch 1994). Podobnego rozróżnienia dokonał Schaffer, który wskazuje agresję wrogą i instrumentalną. Pierwsza wyraża się w działaniach mających na celu wyrządzenie krzywdy lub zranienie ofiar. Agresja instrumentalna występuje, gdy zachowania mogą mieć formę agresywnych i krzywdzących, ale są podejmowane z powodów nieagresywnych (Schaffer 2006).

Wielość publikacji dotyczących agresji i przemocy może świadczyć o tym, że są to zjawiska, które pretendują do miana jednych z najpoważniejszych problemów współczesnego świata. Dotyczą one nie tylko działań zbrojnych toczących się obecnie w wielu miejscach na świecie, życia politycznego, publicznego, społecznego, ale także życia rodzinnego i szkolnego. Liczne badania dotyczące rozmiarów agresji wśród dzieci i młodzieży wskazują, że jest to zjawisko obecne w polskiej przestrzeni szkolnej i stanowi jeden ważniejszych problemów wychowawczych (Ostrowska, Surzykiewicz 2005; Ostrowska 2007; Kulesza 2007; Pyżalski 2012). Badania empiryczne potwierdzają, że agresja w szkole istnieje nie tylko w relacjach pomiędzy uczniami, ale także w relacji nauczyciel - uczeń (Poraj 2004, Ostrowska 2007, Baczko-Dombi i in. 2011, Pyżalski 2015). Jak zauważa Jagieła: „Przemoc mająca miejsce na terenie szkoły stanowi bowiem niezwykle złożoną, wieloaspektową i trudną kwestię o charakterze społecznym, psychologicznym i pedagogicznym, ale - o czym również nie można zapominać - jest także problemem moralnym i aksjologicznym" (Jagieła 2018, s. 43).

Różnorodność perspektyw badawczych zjawiska agresji sprawia, że trudno wskazać jego jedyną przyczynę. Jest ono uwarunkowane wieloczynnikowo. Istnieje wiele różnych modeli teoretycznych opisujących mechanizmy powstawania zachowań agresywnych. Poszukiwanie przyczyn zachowań agresywnych przeszło długą drogę. Wśród koncepcji koncentrujących się na psychologicznych mechanizmach agresji najczęściej są opisywane: teoria instynktów, teoria frustracji - agresji, teoria 
psychoanalityczna i teoria społecznego uczenia się. Pierwsza koncepcja traktuje agresję jako instynkt będący skutkiem procesu ewolucji, niezbędny do utrzymania gatunku i stanowiący swego rodzaju motor i napęd działania. W świetle tego modelu agresja jest zachowaniem wrodzonym i zdeterminowanym biologiczną koniecznością wyładowania agresywnej energii; jego cechą jest także mała podatność na wpływy i proces uczenia się (Wojciszke 2003). Przedstawiciele tej koncepcji, m.in. Zygmunt Freud, Konrad Lorenz, zakładają, że każdy człowiek rodzi się z pewnym instynktem walki, który umożliwia mu zaspokojenie podstawowych i niezbędnych potrzeb do życia oraz skłania człowieka do obrony przed atakiem (por. Miłkowska 2003). Druga koncepcja, reprezentowana przez Johna Dollarda i Neala A. Millera, ujmuje agresję w kategoriach reakcji na frustrację, tj. stan charakteryzujący się napięciem emocjonalnym i niepokojem, który powstaje w efekcie niemożności zaspokojenia potrzeb oraz zrealizowania przez jednostkę założonego wcześniej celu (Dollard i in. 1939). Trzeci koncept w nurcie klasycznej psychoanalizy, stworzonej przez Zygmunta Freuda zakłada, że agresja stanowi pewien manifest nieuświadomionego i wypartego konfliktu pomiędzy dwoma popędami: życia i śmierci. Freud stoi na stanowisku, że „zachowania jednostki napędzane są przez dwie siły, które stanowią nieodłączną część natury ludzkiej. Pierwszą z nich jest instynkt życia (Eros), drugą zaś instynkt śmierci (Thanatos). O ile Eros popycha podmiot do kierunku poszukiwania przyjemności i dążenia do zaspokojenia pragnień, o tyle Thanatos nastawiony jest na autodestrukcję" (za: Krahé 2005, s. 37). W świetle teorii społecznego uczenia się zachowań agresywnych Alberta Bandury oraz Richarda H. Waltersa człowiek uczy się różnych zachowań (w tym form zachowań agresywnych), obserwując zachowania innych ważnych w jego życiu osób (tzw. modeli roli), z którymi przebywa na co dzień (Bandura 1986, 2007; Wojciszke 2003). W tej perspektywie agresji można się nauczyć poprzez obserwowanie aktów agresji, ich naśladowanie, modelowanie, a także poprzez stosowanie wzmocnień negatywnych i pozytywnych (Wojcieszke 2003).

Przestrzeń szkolna, obok rodziny, jest tym środowiskiem, który ma szczególne znaczenie dla kształtowania się osobowości dzieci i młodzieży. Jako specyficzne środowisko wychowawcze i socjalizujące jest źródłem wielu wzorców, modeli i standardów zachowania - nie zawsze zgodnych $\mathrm{z}$ wartościami uniwersalnymi. Jakub Kołodziejczyk wymienia obszary o kluczowym znaczeniu dla wyzwalania, rozwijania lub wzmacniania na terenie szkoły zachowań agresywnych i przemocowych wśród dzieci. Są to czynniki związane ze szkołą jako instytucją oraz jej organizacją; czynniki psychologiczne; czynniki związane z relacjami nauczyciel uczeń. W pierwszej grupie czynników znajdują się m.in. zbyt duża liczba uczniów w klasie; ogólny standard budynku i otoczenia (poziom hałasu, wystrój pomieszczeń, oświetlenie); nauka zmianowa; duża liczebność uczniów w szkole przyczyniająca 
się do anonimowości zarówno uczniów, jak i nauczycieli; niewłaściwa kontrola uczniów oraz częste zmiany nauczycieli. Do czynników psychologicznych zaliczono m.in. frustrację, wynikającą z braku dobrego kontaktu z dorosłymi lub agresji z ich strony oraz spowodowaną brakiem perspektyw życiowych; niskie poczucie własnej wartości; otrzymywanie przez uczniów dużej ilości negatywnych komunikatów od osób dorosłych; brak jasnych reguł życia szkolnego lub ich nieprzestrzeganie. W zakresie relacji nauczyciel - uczeń do czynników potęgujących agresję u uczniów można zaliczyć m.in. niewłaściwy sposób komunikowania się nauczycieli z uczniami, np. krytykowanie czy ośmieszanie; rozwiązywanie przez dorosłych sytuacji konfliktowych w sposób siłowy, stosowanie niekonsekwentnych metod dyscyplinujących uczniów; brak umiejętności nauczycieli w zakresie radzenia sobie z silnymi i negatywnymi emocjami, także tymi wynikającymi z kontaktów z uczniem (por. Kołodziejczyk 2004). Natomiast Ostrowska i Surzykiewicz (2005) dokonali wyodrębnienia czynników agresji uczniów o charakterze typowo szkolnym. Zaliczyli do nich: niskie wyniki w nauce, obniżony poziom motywacji, słabe poczucie więzi ze szkołą, wagary i ograniczone aspiracje związane z karierą zawodową.

\section{BADANIA WŁASNE}

Celem przeprowadzonych badań było zebranie opinii uczniów szkoły podstawowej na temat zachowań agresywnych wobec katechetów, tj. dotyczące rodzaju zachowań agresywnych przejawianych przez uczniów wobec katechetów, przyczyn takich zachowań oraz okoliczności, w jakich najczęściej dochodzi do agresji.

Pytania, na które starano się uzyskać odpowiedź w toku badań:

1. Czy i jakie przejawy zachowań agresywnych wobec katechetów badani uczniowie obserwują u swoich kolegów?

2. Czy i jakie przejawy zachowań agresywnych wobec katechetów prezentuje badana młodzież?

3. Jakie są przyczyny zachowań agresywnych współczesnej młodzieży w opinii badanych?

W badaniach wykorzystano kwestionariusz ankiety własnej konstrukcji. Badania przeprowadzono w czerwcu 2018 roku. Uczestniczyło w nich 70 uczniów szkoły podstawowej, w tym 39 chłopców i 31 dziewcząt. Badani uczniowie to głównie 15-latki (50\%), nieco mniej uczniów w wieku 14 lat (28,6\%) i 16 lat (21,4\%). Wszyscy badani uczniowie uczestniczą w zajęciach katechezy, 80\% uczniów uważa się za osoby wierzące, a $20 \%$ uważa się za osoby niewierzące. Zdecydowania większość badanych, tj. 72,8\%, uczestniczy z lekcjach katechezy, ponieważ chce brać w nich 
udział. Dla 11,4\% badanych głównym powodem uczestnictwa w lekcjach religii jest poczucie obowiązku. Uczniowie, dla których nakaz rodziców jest powodem udziału w katechezach, stanowili 8,7\% badanych. Najmniej liczna grupę stanowili uczniowie, który przyznali się, że uczestniczą w zajęciach z religii tylko po to, aby nie odstawać od grupy $(7,1 \%)$.

Wszyscy ankietowani kojarzyli agresję z niewłaściwym postępowaniem. Wiekszość badanych utożsamiała zjawisko agresji z formami agresji psychicznej/ werbalnej, tj. z krzykiem, wyzywaniem, nękaniem, oczernianiem, pokazywaniem obraźliwych gestów (61,4\%). Z takimi przejawami agresji fizycznej, jak bicie, popychanie, szarpanie zjawisko to wiązało $38,6 \%$ respondentów. Wszyscy badani uczniowie przyznali się do prezentowania zachowań o charakterze agresywnym.

\section{PRZEJAWY I PRZYCZYNY AGRESJI WOBEC KATECHETÓW W OPINII BADANYCH}

Dane uzyskane w wyniku przeprowadzonych badań wskazują, że do najczęściej obserwowanych zachowań wobec katechetów przez badaną młodzież $(78,6 \%)$ należy celowe przeszkadzanie podczas zajęć (np. poprzez wydawanie różnych „dziwnych” odgłosów, rozmawianie z kolegami „nie na temat zajęć”, „głośne śmianie się”). Dość często badana młodzież obserwuje rzucanie w stronę nauczyciela drobnymi przedmiotami, takimi jak kreda, długopis, kulki papieru (47,1\%), nieco rzadziej badani są świadkami wyśmiewania ich poglądów czy wyglądu (44,3\%). Blisko jedna trzecia badanych osób (21\%) obserwuje wśród swoich kolegów pokazywanie obraźliwych gestów wobec katechetów, nieco mniej (20\%) jest świadkiem wyzywania nauczycieli religii. Badani są obserwatorami także takich zachowań wobec katechetów, jak: przyklejanie gumy do żucia na krzesło, na które ma usiąść nauczyciel (10\% respondentów), pisania obraźliwych słów na temat katechety $(8,6 \%)$, grożenia $(8,6 \%)$, opluwania $(7,1 \%)$, plucia do napoju nauczyciela $(7,1 \%)$, chowania przedmiotów potrzebnych do prowadzenia katechezy $(7,1 \%)$, podstawiania nogi $(4,3 \%)$ i szarpania $(4,3 \%)$. Najrzadziej badani uczniowie obserwowali złośliwe komentarze wobec katechetów na portalach społecznościowych (2,9\%). Żaden $\mathrm{z}$ respondentów nie przyznał się do bycia świadkiem bicia katechety. Badanych uczniów poproszono także o wskazanie tych zachowań, które prezentowali sami wobec nauczycieli religii. Połowa badanych uczniów przyznała się do celowego przeszkadzania podczas zajęć (50\%). Dość często badani wyśmiewają się z osoby katechety $(34,3 \%)$ oraz rzucają w stronę nauczyciela drobnymi przedmiotami (27,1\%). Do zamieszczania na różnych portalach społecznościowych złośliwych komentarzy wobec katechetów przyznało się 10\% respondentów. Nieco mniej 
badanych przyznało się do pisania obraźliwych słów na temat nauczyciela religii $(8,6 \%)$, grożenia $(8,6 \%)$. Badani ujawnili również, że przyklejali gumy do żucia do krzesła katechety $(7,1 \%)$, podstawiali nogę $(7,1 \%)$ i pokazywali obraźliwe gesty $(7,1 \%)$. Badani uczniowie przyznali się ponadto do wyzywania nauczyciela religii (5,7\%), opluwania $(2,9 \%)$ i plucia do napoju katechety $(2,9 \%)$. Tylko jedna osoba przyznała się do chowania przedmiotów potrzebnych do prowadzenia lekcji $(1,4 \%)$. Żaden $\mathrm{z}$ respondentów nie przyznał się do szarpania czy bicia nauczyciela religii. Uzyskane rezultaty dotyczące form agresji korespondują z wynikami m.in. badań Baczko-Dombi i in. (2011), w świetle których 20,5\% nauczycieli podczas zajęć ma do czynienia z arogancją uczniów, a 23,9\% nauczycieli spotyka się ignorowaniem poleceń i przeszkadzaniem w prowadzeniu lekcji.

Badanych uczniów poproszono o wskazanie powodów zachowań agresywnych uczniów wobec nauczycieli katechezy. Zdaniem badanych najczęstszym powodem takich zachowań jest chęć zdobycia sympatii kolegów/koleżanek (37,1\%). Nieco mniej respondentów za główny powód agresji uczniów wobec nauczycieli religii uważa przekonanie, że katecheta nie jest nauczycielem (31,4\%). Według 27,1\% respondentów uczniowie zachowują się agresywnie wobec katechetów, ponieważ nie są osobami wierzącymi. Nieco mniej osób $(21,4 \%)$ uważa, że o zachowaniu agresywnym wobec nauczyciela katechezy decyduje chęć rozładowania złości. Ponadto badani zostali poproszeni o wskazanie powodów wzrostu zachowań agresywnych współczesnej młodzieży. Najczęściej badani za główne źródło wzrostu agresji młodzieży wskazywali ogólny wzrost agresji w mediach i społeczeństwie $(44,3 \%)$. Nieco mniej osób $(41,4 \%)$ uważa, że to brak zainteresowania dzieckiem ze strony rodziców jest przyczyną wzrostu agresji młodzieży i pobłażliwy stosunek dorosłych wobec dzieci $(37,1 \%)$. Surowa dyscyplina wychowania to przyczyna wzrostu agresji zdaniem tylko 8,6\% ankietowanych. Respondenci wśród źródeł wzrostu agresji współczesnej młodzieży wskazali ponadto łatwy dostęp do używek $(2,9 \%)$.

\section{PODSUMOWANIE}

Analiza zebranego materiału badawczego pozwoliła stwierdzić, że celowe przeszkadzanie podczas lekcji religii (np. poprzez wydawanie różnych „dziwnych” odgłosów, rozmawianie z kolegami „nie na temat zajęć”, „głośne śmianie się”) jest najczęstszą formą zachowań uczniów. Najpowszechniejszą formą zachowań o charakterze agresywnym podczas lekcji religii w świetle przeprowadzonych badań jest wyśmiewanie się z osoby katechety (jego wyglądu, poglądów) oraz rzucanie w jego stronę rożnymi drobnymi przedmiotami, np. kredą, długopisem, zmiętymi kulkami papieru. Nierzadkie są również obraźliwe gesty wobec katechetów, wyzy- 
wanie wulgaryzmami, pisanie obraźliwych słów na ich temat, grożenie, opluwanie i plucie do jego napojów. W świetle badań nieobce jest badanym uczniom umieszczanie złośliwych komentarzy o katechetach na portalach społecznościowych. Można zatem stwierdzić, że badani uczniowie najczęściej prezentują zachowania agresywne zaliczane do form agresji psychicznej. Badania ujawniły, że badani rzadko sięgają po formy agresji fizycznej. Tylko 4,3\% ankietowanych obserwowało szarpanie nauczyciela przez jakiegoś ucznia i żaden z respondentów nie przyznał się do tej formy agresji. Badana młodzież nie prezentowała agresji w formie bicia.

Wyniki podjętych badań wskazują, że głównymi impulsami zachowań agresywnych wobec nauczycieli religii zdaniem respondentów są: chęć zdobycia aprobaty i sympatii innych uczniów oraz przekonanie uczniów o tym, że katecheta nie jest prawdziwym nauczycielem.

Badania wykazały ponadto, że w perspektywie badanej młodzieży głównym źródłem nasilenia się agresji współczesnej młodzieży jest ogólny wzrost agresji w mediach i społeczeństwie. Badani odpowiedzialnością za wzrost agresji współczesnej młodzieży obarczają także rodziców. Zdaniem ankietowanych brak zainteresowania rodziców dzieckiem i pobłażliwy stosunek dorosłych wobec dzieci to przyczyny nasilenia zachowań agresywnych młodego pokolenia.

Bez wątpienia obraz katechety i lekcji religii w szkole budzi współcześnie wiele dyskusji i emocji. W odniesieniu do zjawiska agresji i powyższych wyników badań warto zastanowić się nad postrzeganiem nauczycieli katechezy przez uczniów oraz wypełnianiem przez katechetów roli zawodowej. Pojawia się bowiem pytanie: dlaczego nauczyciele religii nie są przez uczniów postrzegani jako nauczyciele? Czy wynika to z niedostatków w zakresie kompetencji wychowawczych katechetów? Być może ich przygotowanie pedagogiczne, tj. posiadana wiedza i umiejętności z zakresu psychologii, pedagogiki katechetyki i dydaktyki nauczanych w powiązaniu $\mathrm{z}$ teologią (Porozumienie KEP oraz MEN z dnia 6 września 2000 r.), wymagają pogłębienia, aby budować pożądane relacje $\mathrm{z}$ uczniami i dzięki temu stawać się w ich oczach „prawdziwymi” nauczycielami.

Z uwagi na małą grupę badawczą uzyskane wyniki badań nie upoważniają do ich generalizowania. Mogą jednak inspirować do przeprowadzenia badań na większej próbie badawczej. Mogą również stanowić punkt wyjścia do szerokiej dyskusji na temat funkcjonowania nauczycieli katechezy w świadomości uczniów. 


\section{LITERATURA}

Baczko-Dombi A., Giza-Poleszczuk A., Komendant-Brodowska A., 2011, Przemoc w szkole. Raport z badań 2006 i 2011. Warszawa, https://panoptykon.org/sites/ default/files/sbp2-_szkoly_ost_wersjapdf.pdf [dostęp: 17.09.2018].

Bandura A., 2007, Teoria społecznego uczenia się. Warszawa, PWN.

Baron R.A., Richardson D.R., 1994, Human aggression. New York, Plenum Press.

Buss A.H., 1961, The psychology of aggression. New York Wiley.

CBOS, 2006, Przemoc $w$ Szkole - raport z badań, Badanie zrealizowane na zlecenie dzienników regionalnych grup wydawniczych Orkla Press Polska oraz Polskapresse. Warszawa.

Dollard J., Doob L.W., Miller N.E., MOwrer O.H., Sears R.R., 1939, Frustration and Aggression. New Haven, Yale University Press.

Gruszkowska M., 2004, Społeczne i psychologiczne uwarunkowania agresywności młodzieży w okresie adolescencji. W: A. Rajzner, Agresja w szkole-spojrzenie wieloaspektowe. Warszawa, Wyższa Szkoła Pedagogiczna.

Grzegorzewska I., 2015, Zachowania agresywne dzieci i młodzieży. Ujęcie klinicznorozwojowe. „Polskie Forum Psychologiczne”, t. 20, nr 4, 484-498. DOI:10.14656/ PFP20150403.

Jagieła J., 2018, Transakcyjne modele przemocy szkolnej. „Studia Paedagogica Ignatiana” 21(1), 41-61. DOI: 10.12775/Spi.2018.1.002.

Kendall P.C., 2004, Zaburzenia okresu dzieciństwa i adolescencji. Gdańsk, GWP.

Kołodziejczyk J., 2004, Agresja i przemoc w szkole. Konstruowanie programu przeciwdziałania agresji i przemocy w szkole. Kraków, NODN „SOPHIA”.

Krahe B., 2005, Agresja. Gdańsk, GWP.

Kulesza M., 2007, Klimat szkoły a zachowania przemocowe uczniów w świetle wybranych badań empirycznych. „Seminare”, 24, 261-277.

Leymann H., 1996, The content and development of mobbing at work. „European Journal of Work and Organizational Psychology", 5(2). DOI: 10.1080/13594329608414853.

Miłkowska G., 2003, Agresja. Encyklopedia Pedagogiczna XXI wieku, t. I.

Mościcka A., Drabek M., 2010, Mobbing w środowisku pracy nauczyciela. W: J. Pyżalski, D. Merecz (red.), Psychospołeczne warunki pracy polskich nauczycieli. Pomiędzy wypaleniem zawodowym a zaangażowaniem. Kraków, Oficyna Wydawnicza Impuls, 75-98.

Ostrowska K., 2007, Rozmiary, nasilenie i rodzaje zachowań agresywnych $w$ szkole w latach 1997, 2003, 2007. Raport z badań. Warszawa, Ośrodek Rozwoju Edukacji.

Ostrowska K., 2008, Agresywne zachowania uczniów w świetle badań porównawczych z 1997 i 2003 roku. W: M. Libiszowska-Żółtkowska, K. Ostrowska (red.), Agresja w szkole. Diagnoza i profilaktyka. Warszawa, Wydawnictwo Diffin. 
Ostrowska K., Surzykiewicz J., 2005, Zachowania agresywne w szkole. Badania porównawcze 1997 i 2003. Warszawa, CMPPP - Centrum Metodyczne Pomocy Psychologiczno-Pedagogicznej.

Poraj G., 2004, Doświadczanie agresji i przemocy w szkole. „Acta Universitatis Lodziensis. Folia Psychologica", 8, 19-31. DOI: 11089/1635.

Poraj G., 2009, Od pasji do frustracji: modele psychologicznego funkcjonowania nauczycieli. Łódź, Wydawnictwo Uniwersytetu Łódzkiego.

Porozumienie pomiędzy Konferencją Episkopatu Polski oraz Ministrem Edukacji

Narodowej z dnia 6 września 2000 r. w sprawie kwalifikacji wymaganych od nauczycieli religii (Dz. Urz. MEN Nr 4, poz. 20).

Pyżalski J., 2012, Agresja elektroniczna i cyberbullying jako nowe ryzykowne zachowania młodzieży. Kraków, Oficyna Wydawnicza Impuls.

Pyżalski J., 2015, Przemoc rówieśnicza w szkole - badania retrospektywne studentów pedagogiki. „Studia Edukacyjne”, 34, 177-196. DOI: 10.14746/se.2015.34.1.

Schaffer H.R., 2006, Rozwój społeczny. Dzieciństwo i młodość. Kraków, Wydawnictwo Uniwersytetu Jagiellońskiego.

Strutyńska E., 2014, Mobbing wśród nauczycieli. Zakres i uwarunkowania. Radom, Wydawnictwo Naukowe Instytutu Technologii Eksploatacji.

Surzykiewicz J., 2000, Agresja i przemoc w szkole. Uwarunkowania socjoekologiczne.

Warszawa, Centrum Metodyczne Pomocy Psychologiczno-Pedagogicznej.

Vasta R., Haith M.M., Miller S.A., 2004, Psychologia dziecka. Warszawa, WSiP.

Wojcieszke B., 2003, Człowiek wśród ludzi. Zarys psychologii społecznej. Warszawa, Wydawnictwo Naukowe Scholar.

Zimbardo P., Ruch P., 1994, Psychologia i życie. Warszawa, PWN.

\title{
AGGRESSIVE BEHAVIOUR BY STUDENTS
}

\section{TOWARDS RELIGIOUS EDUCATION TEACHERS}

\begin{abstract}
Schools today are being faced with numerous disciplinary challenges. Aggressive behaviour has become more common in the school environment, and it continues to escalate in terms of the target and manner in which it is expressed, which is why this problem cannot be ignored. Teachers, including religious education teachers, have become more commonly the target of aggression. It is difficult to estimate the level of student aggression towards teachers, as the latter often choose not to report abusive behaviour by students. The aim of the article is to raise the awareness of the position of religious education teachers in terms of aggressive behaviour by students. The article includes the author's own research, which illustrates the school reality in the context of aggressive behaviour by students towards religious education teachers.
\end{abstract}

Keywords: aggression, teacher, religious education teacher 